УДК 796.5(477)

\title{
PECULIARITIES TO USE THE INTERNATIONAL EXPERIENCE FOR THE DEVELOPMENT MANAGEMENT OF TOURISM INDUSTRY IN UKRAINE
}

\author{
Podzigun S. M., Korol I. V., Maliarchuk N. M.
}

\begin{abstract}
Анотація. У статті визначено основні напрями розвитку туристичної сфери в Україні. Проаналізовано досвід розвинутих країн і країн, що розвиваються, для формування пропозицій стосовно подальшого розвитку туристичної сфери України та підвищення її конкурентоспроможності в умовах інтеграції української економіки у світове господарство. Досліджено питання впровадження досвіду стратегічного управління провідних європейських туристичних країн на трьох рівнях - національному, регіональному та рівні туристичних підприємств.
\end{abstract}

Ключові слова: стратегічне управління; туристична галузь; розвиток туризму; державне регулювання туризму; туристичне підприємство.

Аннотация. В статье определены основные направления развития туристической сферы в Украине. Проанализирован опыт развитых стран и развивающихся стран, для формирования предложений по дальнейшему развитию туристической сферы Украины и повышения ее конкурентоспособности в условиях интеграции украинской экономики в мировое хозяйство. Исследован вопрос внедрения опыта стратегического управления ведущих европейских туристических стран на трех уровнях - национальном, региональном и уровне туристических предприятий.

Ключевые слова: стратегическое управление; туристическая отрасль; развитие туризма; государственное регулирование туризма; туристическое предприятие.

The problem's setting and its connection with other scientific and practical tasks. In modern Ukraine the awareness of the importance of tourism development as one of the effective means of national economy treatment has already taken place due to the ability of this sector to provide significant foreign exchange earnings, create a huge number of new jobs and other benefits. The strategic goal of the tourism industry development in Ukraine is to bring it to the world level of tourist services. The main conditions for this are: geographical location, the availability of natural, historical and archaeological tourism potential, political stability and economic growth, competitiveness of tourist services.

The analyses of resent publications on the theme. The problem of improving the system of strategic management of tourism development is considered in the research works of E. B. Adelseitova, E. R. Ab-duraimova, V. S. Kucherenko, T. I. Tkache-nko and others. International aspects of the

62 tourism industry development are described in the works of O. V. Bartoshuk, V. G. Gerasymenko, S. S. Galasyuk, M. P. Malskaya, N. V. Antonyuk, N. M. Ganich and others.

The aim of the article. The objective of the article is to analyze the foreign experience of development management in the tourism industry and to develop recommendations for its use in the functioning of the tourism industry in Ukraine.

The main results and its grounding. Tourism is a complex socio-cultural and historical phenomenon. Being just a form of leisure time activities, it gradually turned into a factor of world significance of the new century and the millennium. Tourism plays an exclusively priority role in the formation of communicative culture that is adequate to the current stage of the transition to the 21st century civilization [6].

The tourism business can be considered a business of the 21st century, because it is one of the most dynamic and profitable among all sectors of the world economy. According to 
the World Tourism Organization, tourism takes $10 \%$ of gross world product, $7 \%$ of total investment, and $5 \%$ of all tax revenues. Tourist activity directly affects about 40 branches of the economy. It employs $10-15 \%$ of the ablebodied population of the world [4]. The trends taking place in the economies of many countries of the world show the rapid growth of the role of tourism for the development of these countries, as well as the steady increase in the share of revenue from the tourism industry to the state treasury. This is due to the dynamism, high profitability and great positive socio-economic and cultural impact of tourism on the development of these countries.

In modern conditions, strategic management is a necessary component of the activities of all enterprises, regardless of the sphere or type of their activities. Strategic management of enterprises of the tourist industry is based on the general concepts and provisions that take place in other sectors of the economy, and at the same time, it has a number of features in the implementation of individual strategies, which are determined by the specifics of the tourism industry as a whole.

The main direction of strategic development for tourism enterprises is the focus on effective strategic management of activities, taking into account the changes in the tourist services market and socio-economic environment in general. It is the system of strategic management of tourism development throughout the region gives the tourist enterprises to combine the general development strategy with the availability of real and potential opportunities for its implementation, taking into account the threats that can occur on the market [2].

In the countries of the world there are various approaches to the creation and functioning of regulatory authorities for the development of the tourism industry. This is due to the specific social and economic and political conditions of the development of individual states, the level of significance and the scale of tourism in the national economy.
The first (market) model involves the absence of a central state tourist administration, as well as the central governmental authority. All issues related to the development of tourism, are solved at the regional level or independently by economic entities on the basis of operational regulation and principles of a market economy. The main condition for the possibility of using this model is that the country should be attractive to foreign tourists from all perspectives and do not need to specifically advertise a national tourist product on the world market.

Important in this case is the developed infrastructure, the system of ensuring the safety of tourists, the high level of provision of banking, insurance services and medical care.

The second model of tourism development involves the presence of a special, powerful, authoritative and independent central governmental authorities (ministries, departments, etc.) that develop and control the activities of the entire tourism industry. The Ministry has significant powers in the field of investment, marketing research, personnel training, advertising, etc. Such a model requires significant financial investments in the development of tourism infrastructure, promotion of a domestic tourism product, etc. This model is used by countries for which tourism is an important industry bringing significant revenues to the state budget. These are, for example, Egypt, Mexico, Tunisia, Greece, and others.

The implementation of this model requires significant financial investments in the development of the tourism industry in order to create and maintain a high-level national tourist product and tourist infrastructure, to provide state support to small and medium-sized business, to create a security system for tourists, etc.

The third (European) model of state participation in the development of the tourism industry prevails in the developed European countries. It assumes that the issues of tourism development are solved at the level of a 
specialized branch unit (centralized structure, state authority), which operates within multisectoral, multifunctional ministries (most often of economic orientation) or directly subordinate to the government, but has the status of a relatively independent administrative body $[1 ; 4]$.

It is advisable to consider the European model of development in more detail, because it seems to be the most acceptable for Ukraine. Typical features of this type of tourism development are the following: coordination of interests of the state, local authorities and private business; mutually beneficial forms of cooperation between the authorities of the macro- and microeconomic levels; in countries there are many other organizations involved in tourism development (they are administratively subordinated to the above-mentioned structures or operate autonomously). Such a scheme of work proved to be quite productive for attracting financial resources from the private sector to solve the urgent tasks of the national economy development [4].

Thus, on the basis of the analysis, we would like to emphasize that separate elements of the mechanisms of state regulation of the tourist industry of the above mentioned countries, the effectiveness of which is verified by time and confirmed by concrete achievements in the development of tourism, it is expedient to use for the tourist industry development in Ukraine, taking into account its historical, legal and cultural peculiarities.

In addition, the important is the implementation of the state policy of Ukraine in the field of tourism, which is carried out by defining the main directions of the state policy, priority directions of tourism development, classification and evaluation of Ukrainian tourist resources, their use and protection, and directing budget funds for the development and implementation of tourism development programs. Important for the implementation of state policy is the identification of the tourism security, statutory regulation of relations in the field of tourism (tourist, hotel, excursion and other types of services), licensing in tourism, standardization and certification of tourist services, determination of qualification requirements for positions of specialists of tourist support, issuance of permits for the right to carry out tourist assistance, establishment of the system of statistical accounting and reporting in tourism as well as resort and recreation complex, organization and state control over statutory compliance in tourism [6].

Globalization of economic processes is one of the main factors of the modern system of international and national tourism industry, accompanied by a concentration of market segment under the influence of large companies. In recent years, the new technologies are introduced in tourism management, which primarily include tourist clusters formed on the basis of a large tourist enterprise and represent a set of interconnected and auxiliary enterprises that ensure the operation of tourism activities in a certain area. At the same time, changes in tourism management lead to qualitative changes in the tourism industry (for example, the formatting of tourist services and the emergence of network products).

Today, the process of forming tourist networks in Europe, together with hotels, includes also museums, castles (as historical monuments and places of tourist locations), nodal points of intersection of transport and tourist routes [3]. The integration process of tourist networks covers many other aspects and levels of tourism activity. At the same time, tourist networks of specific foreign countries form the consumers' bases, introduce general standards of document circulation, quality of service, a set of additional services, create interregional routes, which combine tourist objects according to a network principle in one format [9].

In addition, "shopping" is a significant part of the modern tourist product. At the same time, the Ukrainian retail market only recently emerged from the stage of unorganized trade and is at the stage of growth of the organized segment, as well as the evolution of retail 
formats. Also its development significantly accelerates the arrival of Western retail networks.

According to the research of European tourism business development specialists, for the last ten years most tourist companies are trying to organize a unified management for all components of the tourist complex - from the creation of various tourist destination products to ensuring the reliability and implementation of the plan to promote the tourist offer. Therefore, the main features of strategic management are the following:

1) strategic management is the projected development of the company, rather than an accurate and detailed description of its position and location in the business environment;

2) the system of strategic management is a peculiar philosophy and business ideology, which should not be reduced to formalized set of procedures, because when developing a strategy together with the rules, it is necessary to combine the intuition, professionalism and creativity of managers, able to involve all employees of the company in the implementation of the strategy;

3) in market conditions, mistakes made when choosing a strategy cannot be corrected by any effective methods of operational management, which can lead to defeat in the competition [7].
Conclusions and further prospects of the research. The modern conditions of world integration processes and the importance of ensuring the development of the tourism industry requires managerial decisions of organizational structures not only at the national and regional levels, but also those created within the framework of cross-border cooperation and participation in European and world organizations. Such bodies mostly have a non-public status, however, effective cooperation with them allows the exchange of experience, the implementation of joint projects, and the development of tourism infrastructure [8].

But the effectiveness of its implementation will only manifest itself only in the combination of strategic management at all levels of the tourism industry development, namely national, regional and tourism enterprises level, which will bring the tourism business in Ukraine to a qualitatively higher level of development. In our opinion, it is appropriate to develop a model of strategic tourism development management, which should combine elements of domestic state regulation of this industry, as well as experience of other European countries, which are of great importance in the management and cooperation with private entities of tourism industry.

\section{References}

1. Bartoshuk, O. V. (2011), "Models to develop the tourism industry (foreign experience)", Derzhava i rehiony. Seriia: Ekonomika ta pidpryiemnytstvo, no. 2, pp. 62-68.

2. Herasymenko, V. H. and Halasyuk, S. S. (2008), "Management of national tourism in the context of international experience", Visnyk DITB. Seriia: Ekonomika, orhanizatsiia $i$ upravlinnia pidpryiemstvamy (v turystychnii sferi), no. 12, pp. 19-24.

3. Bratyuk, V. (2012), "Analysis of the experience of Western countries in the enhancing the state policy to promote tourism development", Aktualni problemy ekonomiky, no. 9, pp. 63-71.

4. Malska, M. P., Antonyuk, N. V. and Hanych, N. M. (2008), Mizhnarodnyi turyzm i sfera posluh [International tourism and services], Znannya, Kyiv, Ukraine.

5. Liubitseva, O. O., Kiptenko, V. K., Stafiichuk, V. I. and Khilchevska, I. H. (2010), Turystychne krayinoznavstvo: krayiny - lidery turyzmu [Travel country studies: countriesleaders in tourism], Alterpres, Kyiv, Ukraine.

6. Vedmid, N. I. and Melnychenko, S. V. (2001), "Improving management of marketing communications of tourism enterprises", Visnyk DITB, no 5, pp. 107-112. 
7. Adel'seitova, Je. B. and Abduraimova, Je. R. (2012), "Strategic management of tourism industry enterprises", Kul'tura narodov Prichernomor'ja, no. 235, pp. 7-8, [Online], available at: http://tourlib.net/statti_tourism/adelseitova.htm (Accessed 28 May 2017).

8. Kucherenko, V.S. (2010), "Features and contemporary trends in the tourism sector management", Naukovyi visnyk Instytutu mizhnarodnykh vidnosyn NAU. Seriia: Ekonomika, pravo, politolohiia, turyzm, vol. 1, pp. 184-192.

9. Tkachenko, T. I. (2006), Stalyy rozvytok turyzmu: teoriya, metodolohiya, realiyi biznesu [The steady tourism development: theory, methodology, business realities], Kyivskyi natsionalnyi torhovelno-ekonomichnyi universytet, Kyiv, Ukraine.

Бібліографічний опис для цитування:

Podzigun, S. M. Peculiarities of use of the international experience of the development management of tourism industry in Ukraine / Podzigun S. M., Korol I. V., Maliarchuk N. M.// Науковий журнал «Економічні горизонти». - 2017. - № 1(2). - С. 62-66. 